\title{
86 大腿大腿動脈交差バイパスにおけるスチール現象と
} 臨床的意義

\section{東京医科歯科大学 第 1 外科 \\ 村岡幸彦岩井武尚佐藤彰治桜沢健一 木下 晴 之}

非解剖学的バイパスは侵襲が少なくかつ開存性も良好 なととから高齢者を中心にこの術式を採用する機会が多 くなってきた，しかしながら，乙のバイパスで最あ重要 なととは健側 (donor) 下肢をいかに保護するような工 夫をするかが大きな課題である，とくに大腿大腿動脈交 差 (FF) バイパスではスチール現象や患側 (recipient) 下肢への血流の流れすぎが生じないようバランスのとれ た術式を行う必要がある.

\section{対象および方法}

当科で昭和 54 年 1 月から平成元年 5 月までに施行さ れた 53 例の $\mathrm{FF}$ バイパスのうち閉塞性病変の多発しゃ すい閉塞性動脈硬化症の 48 例についてスチール現象の 検討を加えた. 平均年齢は 69.5 歳で男性 39 例, 女性 9 例であった. その大多数が待機手術例であり, 一部 limb salvage 手術として緊急に施行した例ああった。 主訴は間久性跛行 37 例, 安静時痛 2 例, 足趾潰瘍例あ るいは急性下肢虚血例 9 例であった. 両下肢の鼠径靯帯 以下の run off は donor 側のほうが recipient 側より 不良な症例が 4 例ありその他は donor 側のほうが run off 良好あるいは両側で同等な症例であった. また両側 とあ深大腿動脈しか開存していなかった run off の不 良な症例が 4 例あった。 FF バイパスの主たる吻合法は donor 側はグラフトとdonor 動脈をほぼ直角に吻合し recipient 側はやや吻合口を末梢側に延ばした J 型吻合 を採用した．Ｉnflow を改善するために腸骨大腿動脈 (IF) バイパスを 5 例に付加し，また既存の IF バイパス を donor 動脈として 2 例で使用した. Percutaneous transluminal angioplasty（以下 PTA）を donor 側腸 骨動脈に術前に 5 例, 術中に 1 例施行した. 一方, 末梢 側 run off 改善のために recipient 側に深大腿動脈形成 術を 9 例, 腰部交感神経節切除術を 7 例, 腰部交感神経 節ブロックを 4 例に施行した. Donor 側の血流を保持
するために donor 側のほうが run off 不良な 1 例と両 側とも梁大腿動脈しか開存していなかった 1 例で donor 側に深大腿動脈形成術を施行した．使用したグラフト径 は $8 \mathrm{~mm} 31$ 例, $6 \mathrm{~mm} 9$ 例, $10 \mathrm{~mm} 6$ 例, $9 \mathrm{~mm} 1$ 例 であった.グラフトの材質は knitted Dacron 30 例, PTFE 12 例, woven Dacron 3 例, EXS 2 例であっ た.

スチール現象の有無を検索するために電磁血流計によ り両下肢血流量を FF バイパス前後で同時測定し，さら に recipient 動脈末梢側ヘパパベリシ $20 \mathrm{mg}$ を動注し た前後でも同様に測定した。. Donor 側下肢血流量がパ パベリン負荷前後で $20 \%$ 以上減少した場合にスチール が生じていると判定した.

\section{結果}

1. FF バイパス造設前後での血流変化（図 1)

IF バイパス併設例を除く 21 例で測定しており donor

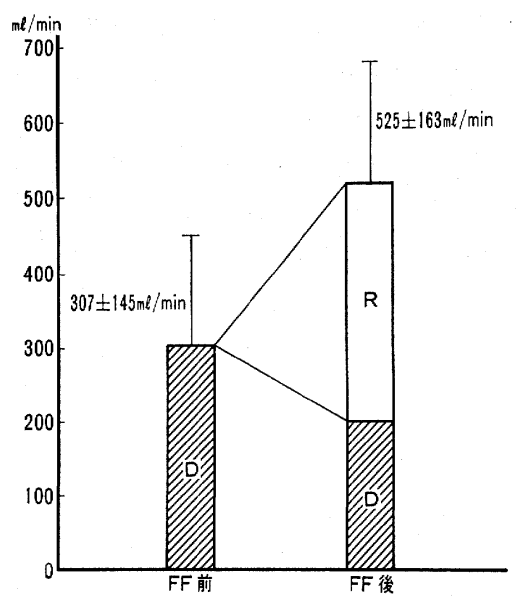

図 $1 \mathrm{FF}$ バイパス前後での donor 側腸骨動脈血流量 D: donor 倪下肢血流量, $\mathrm{R}$ ： recipient 側下肢血流量, (mean \pm SD) 


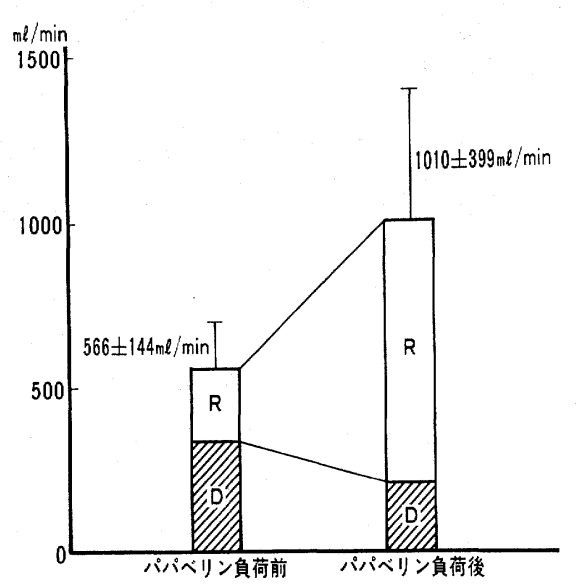

図 2 パパベリン負荷前後での donor 側腸骨動脈血流量 $\mathrm{D}$ : donor 側下肢血流量, R: recipient 側下肢血流量, (mean $\pm \mathrm{SD}$ )

側下肢血流量はバイパス後に 13 例で $20 \%$ 以上の減少 を認め donor 動脈の mean flow はバイパス前平均 307 $\pm 145 \mathrm{ml} / \mathrm{min}$, 後 $200 \pm 86 \mathrm{ml} / \mathrm{min}$ であった. しかし donor 側腸骨動脈系の血流量を示す画下肢血流量の総和 は平均值で $525 \pm 163 \mathrm{ml} / \mathrm{min}$ となり, バイパス後に増加 あるいは不変であった例が 21 例中 19 例であった. 血 流量増加はバイパス前の 5.1 倍が最大であった. また recipient 側ではバイパス前後で $83 \pm 110 \mathrm{ml} / \mathrm{min}$ から $325 \pm 143 \mathrm{ml} / \mathrm{min}$ と著明に改善していた.

\section{Recipient 側血流増加によるスチール現象}

(図 2)

Recipient 側動脈末梢側にパパベリンを負荷して血流 量を増加させ donor 側の血流量変化を 16 例で検討し たところ recipient 側動脈血流量は負荷前の $1.3 \sim 5.6$ 倍に增加し平均值では負荷前 $234 \pm 110 \mathrm{ml} / \mathrm{min}$ から負 荷後 $811 \pm 405 \mathrm{ml} / \mathrm{min}$ となった. Donor 側腸骨動脈系 血流量は負荷前後で不変のものから 3 倍となった例まで あり平均值は $566 \pm 144 \mathrm{ml} / \mathrm{min}$ から $1010 \pm 399 \mathrm{ml} / \mathrm{min}$ 之増加した。一方, donor 側下肢血流量は平均値では $332 \pm 137 \mathrm{ml} / \mathrm{min}$ 加 $199 \pm 107 \mathrm{ml} / \mathrm{min}$ 一之低下し, 6 例では $20 \%$ 以上の低下が認められた。減少例中 3 例は donor 側のほうが run off 良好な症例で, 2 例は donor 側之 recipient 側の run off がほぼ同等な症例，1例は recipient 側のほうが run off 良好な症例であった. 残 り 10 例では不変あるいは增加していた.

\section{FF バイパス前とバイパス後パパベリン負荷時の donor 側下肢血流量の比較}

13 例で検討しているが 2.4 倍血流量の増加した例,
ほぼ不変であった 2 例を除く 10 例で donor 側血流量 は平均で前值の $47 \%$ 減少していた.

\section{考察}

$\mathrm{FF}$ バイパスは従来より認められているように非解剖 学的バイパスにあかかわらず開存性に優れ患者に対する

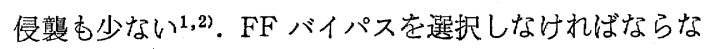
い症例においては donor 側にも高度の動脈硬化性変化 が合併することが多く donor 側の下肢血行をいかにし て保持するかが問題となる. Ehrenfeld ら ${ }^{3)}$ が大の実験 で証明したように閉塞性病変のない腸骨動脈は FF バイ パスによる血流量増加に十分対応できる. そこで inflow が原因となるスチール現象を防止するため術前あるいは 術中の PTA や IF バイパスなどが付加手術として必要 になる. 自験例のうち動脈造影, 超音波ドップラー法 での術前検査で donor 動脈澺の狭窄がないと判断 された症例では $\mathrm{FF}$ バイパス造設後に $71 \%$ の症例で donor 側腸骨動脈血流量は増加している.したがって donor 動脈血流供給能力については中枢側に有意の狭 窄がない限り問題はほとんどないと考えられる.また， パパベリン負荷を行い recipient 側下肢血流量を增加さ せてあ FF バイパス後の約 2 倍の血流量増加が得られ ているととから donor 動脈血流供給能力は術前検査で 病変がなければスチール現象の原因になることはないと 考えられる.つぎに両下肢の run off に不均衡がありパ パベリン負荷時にスチール現象が生じる場合が考えられ る が，このような症例は術前動脈造影で両下肢 run off が不良である上に donor 側下肢 run off が recipient 側より不良という症例で 4 例あった. 術中パパベリ ン負荷を施行した 1 例では donor 側に深大腿動脈形成 術を施行したにあ関わらずスチール現象が生じている. 一方, 術前動脈造影では donor 側のほうが明らかに run off 良好あるいは両下肢 run off が同等と判断した 症例でもスチール現象を生じていた. Donor 側 run off 不良例に対しては donor 側に深大腿動脈形成術, 大腿 膝䆚動脈バイパスや腰部交感神経節切除（あるいはブロ ック）が必要と考えられる．しかし術中パパベリン負 荷でスチール現象を生じた症例で術後 donor 側下肢の ankle pressure index 低下やスチール現象による臨床症 状は認められず間欠性跛行などの症状む全例改善してい る.したがって, 術中スチール現象を生じた症例では術 後あスチール現象が生じている可能性はあるが臨床的に は問題にならない程度であると考えられる。 


\section{結語}

$\mathrm{FF}$ バイパスは非解剖学的バイパスではあるが開存性 あ良好で患側と同様に閉塞性病変の存在する健側下肢血 流量に対する影響む十分に考慮した術式を加えればより 適応を拡大することができると考えられる．また術中パ パベリン負荷による患側血流量増加で健側にスチール現
象の生じた症例屯認めたが臨床症状を呈した例はなく臨 床上は問題とならないと思われた。

文献 1) 松原純一ほ加：外科 48:167, 1986. 2) 木村 誠ほ加：日心外会誌 16:446, 1987. 3) Ehrenfeld, W.K. et al.: Am. J. Surg. 116: 192, 1968, 4) 早川 宏: 脈管学 23 : 1037, 1983. 